\title{
Model-based evaluation of the contribution of partial denitrification (PD) on the one-stage autotrophic nitrogen removal process
}

Chi Zhang ( $\square$ zc_0611@126.com)

Yangzhou University https://orcid.org/0000-0001-5539-5562

Lianze Yu

Yangzhou University

Miao Zhang

Yangzhou University

Jun Wu

Yangzhou University

\section{Research Article}

Keywords: 1D multi-population biofilm model, Partial nitritation-anammox, Total nitrogen removal efficiency, Partial denitrification, One-stage autotrophic reactor

Posted Date: February 3rd, 2021

DOl: https://doi.org/10.21203/rs.3.rs-179960/v1

License: (a) This work is licensed under a Creative Commons Attribution 4.0 International License. Read Full License 


\section{Abstract}

The nitrate produced by the one-stage partial nitritation-anammox (PN/A) process can be removed through partial denitrification (PD) by adding carbon source. In this study, a 1D multi-population biofilm model was developed to evaluate the contribution of partial denitrification on the one-stage autotrophic nitrogen removal process at influent $\mathrm{NH}_{4}{ }^{+}=100 \mathrm{mg} \mathrm{N} / \mathrm{L}$. The dynamic simulation that was carried out to investigate the effect of nitrite-oxidizing bacteria (NOB) revealed that PD contributed to the reactor to obtain total nitrogen removal efficiency (TNR) of above $90 \%$ and the effluent nitrate was significantly decreased with the absence of NOB. However, PD decreased TNR of the one-stage PN/A process with the presence of NOB. Increased influent chemical oxygen demand (COD) widened the dissolved oxygen (DO) range required for high TNR whether NOB were present or not. The steady-state simulation results showed that NOB were always absent in the granules at high DO and COD levels and the optimum DO > $0.5 \mathrm{mg} / \mathrm{L}$ when influent COD was over $50 \mathrm{mg} / \mathrm{L}$. Besides, higher influent $\mathrm{COD} / \mathrm{NH}_{4}{ }^{+}(\mathrm{C} / \mathrm{N})$ and larger granule diameter (diameter $>1600 \mu \mathrm{m}$ ) were contributed to widening the range of DO required for high TNR. The nitrogen removal contribution of anammox bacteria (AMX) was significantly higher than denitrification in the reactor.

\section{Introduction}

Traditional nitrification and denitrification method needs high aeration and COD consumption, so how to remove nitrogen with high efficiency and low consumption has always been one of the key issues in wastewater treatment. Mulder et al. (1995) discovered the anammox process, Strous et al. (1999) found that the anammox process can effectively remove ammonium and nitrite in wastewater with high ammonia nitrogen (such as sludge digestion effluent) through experimental research and consume low energy, so it is a sustainable wastewater nitrogen removal technology (Kartal et al. 2010). The world's first full-scale anammox reactor with granular sludge was built in Dokhaven wastewater treatment plant (WWTP) in Rotterdam, the Netherlands (van Loosdrecht et al. 2004), marking the official commissioning of anammox into operation. The anammox process is shown in Eqs. 1 (Strous et al. 1999). Due to anammox process can be influenced by completely nitrification resulting in poor TNR (Pérez et al. 2014), the one-stage PN/A process which is used to achieve partial nitrification has been proposed to improve autotrophic nitrogen removal (Ganigue et al. 2007).

$$
\begin{aligned}
& \mathrm{NH}_{4}^{+}+1.32 \mathrm{NO}_{2}^{-}+0.06 \mathrm{HCO}_{3}^{-} \rightarrow 1.02 \mathrm{~N}_{2}+0.26 \mathrm{NO}_{3}^{-}+0.66 \mathrm{CH}_{2} \mathrm{O}_{03} \mathrm{~N}_{0.15}+2.03 \mathrm{H} \mathrm{H}_{2} \mathrm{O} \\
& 1.32 \mathrm{NO}_{3}^{-}+0.55 \mathrm{CH}_{3} \mathrm{COO}^{-}+0.088 \mathrm{NH}_{4}^{+} \rightarrow 1.32 \mathrm{NO}_{2}^{-}+0.66 \mathrm{HCO}_{3}^{-}+0.198 \mathrm{H}^{+}+ \\
& 0.088 \mathrm{C}_{3} \mathrm{H}_{7} \mathrm{NO}_{2}+0.264 \mathrm{H}_{2}
\end{aligned}
$$

One of the deficiencies of the one-stage PN/A process is that the effluent nitrate that is produced by AMX cannot be treated. The effluent nitrate can be removed by denitrification bacteria through the PD process, so TNR can be removed up to $100 \%$ theoretically (Cao et al. 2019). Thus, controlling the nitrate only reduction to nitrite is considered to be a new technique called partial denitrification (PD) or short-cut 
denitrification and is arguably one of the most promising technologies for future nitrogen removal processes (Shi et al. 2019; Xu et al. 2020; Zhang et al. 2020). Eqs. 2 is a PD process in which acetate is used as a carbon source (Du et al. 2017a) by controlling the reduction reaction of $\mathrm{NO}_{3}{ }^{-}$in the first stage. However, most experiments on the PD process were based on reactors such as SBR without aeration (Du et al. 2015; Wang et al. 2019) or UASB (Du et al. 2017b; Xu et al. 2020) and the contribution of PD on the one-stage autotrophic reactor with the presence of NOB has hardly been reported. Besides, one of the shortcomings of autotrophic nitrogen removal is to treat influent COD (Sliekers et al. 2002) because of the high sensitivity of AMX activity to COD (Chamchoi et al. 2008; Jin et al. 2012), thus, the anammox process is only considered to be suitable for removing wastewater with no influent organic carbon (Jin et al. 2012; Wang et al. 2016). To solve this problem, anammox coupled with the heterotrophic nitrogen removal process is proposed. For example, Hao and van Loosdrecht (2004) used a model that can simulate the activities of heterotrophic and autotrophic biomass in biofilms and relate reactions such as COD oxidation, denitrification, nitrification, and anaerobic ammonia oxidation to evaluate the heterotrophic and autotrophic nitrogen removal. When the influent COD is too high, will the proliferation of denitrifying bacteria affect AMX activity? Therefore, two types of pressing problems remain about current research on the PD process. First, whether the PD process has an impact on AMX activity and the $\mathrm{NO}_{3}{ }^{-}$generated by AMX can be treated effectively. Second, whether the presence of NOB enables the PD process to help to improve TNR in the one-stage autotrophic reactor.

In this study, a 1D multi-population biofilm model was developed for a one-stage autotrophic reactor to evaluate the nitrogen removal performance of the PD process at high DO levels (presence of NOB) versus low DO levels (absence of NOB) and the main TN removal contributor in each of the conditions. The simulation results enabled the PD process to operate more reliably under a variety of different influent conditions in a one-stage autotrophic reactor.

\section{Granular sludge reactor model}

\section{Stoichiometric matrix, kinetic expressions and model parameter values}

The nitrogen removal process in the one-stage autotrophic granular sludge reactor was simulated by a 1D multi-population biofilm model (Wanner and Reichert 1996). The stoichiometric matrix, kinetic expressions, and model parameter values are summarized in the Supplementary Material (Tables S1S3). Five particulate components (ammonium-oxidizing bacteria (AOB), NOB, heterotrophic bacteria (HET), AMX, and inert biomass (INT)), and five soluble components (soluble biodegradable COD (SS), DO, $\mathrm{NH}_{4}{ }^{+}, \mathrm{NO}_{2}{ }^{-}$, and $\mathrm{NO}_{3}{ }^{-}$) were included in the model. Nitrification was described as a two-step process: oxidation of $\mathrm{NH}_{4}{ }^{+}$to $\mathrm{NO}_{2}{ }^{-}$by $\mathrm{AOB}$, followed by $\mathrm{NO}_{2}{ }^{-}$oxidation to $\mathrm{NO}_{3}{ }^{-}$by $\mathrm{NOB}$. Heterotrophic growth reactions were included using $\mathrm{DO}, \mathrm{NO}_{2}{ }^{-}$or $\mathrm{NO}_{3}{ }^{-}$as an electron acceptor. As in most denitrification models, denitrification was divided into two separate reactions in which both nitrate and nitrite are involved, as anammox bacteria competed with denitrification bacteria for nitrite (Sin et al. 2008). Therefore, the model consisted of heterotrophic and three types of autotrophic bacteria in the granules. The competitions for 
oxygen, ammonium, nitrite, and nitrate between the three types of autotrophic organisms and the heterotrophic bacteria present were considered in the model. Detailed process stoichiometry and rate expressions are listed in Tables S1 and S2 of the Supplementary Material.

\section{Simulation parameters and initial conditions of the reactor}

The model only considering radial gradients in spherical biomass granules was set up to describe the autotrophic and heterotrophic interaction. Spherical granules were grown from an initial diameter of $7.5 \times$ $10^{-4} \mu \mathrm{m}$ to a predefined steady-state granule diameter $(750 \mu \mathrm{m}$ by default, and then varied from 400 to $2000 \mu \mathrm{m}$ to examine the effect of granule size) and were equally divided into 31 layers to simulate the distribution of substrates and microorganisms. The oxygen levels were assumed from 0.1 to $5 \mathrm{mg} / \mathrm{L}$ to evaluate the performance of the one-stage reactor at different influent COD levels, while the temperature was set at $20^{\circ} \mathrm{C}$. The influent ammonium concentration was fixed at $100 \mathrm{mg} \mathrm{N} / \mathrm{L}$ at any simulation with no nitrite or nitrate presenting in the influent and the initial mixed liquor volatile suspended solids (MLVSS) was assumed at $3000 \mathrm{mg} / \mathrm{L}$ in the granules. The influent COD concentration was varied from 0 to $600 \mathrm{mg} / \mathrm{L}$ to evaluate the effect of organic carbon on the reactor performance. The density in the granules was set to $93333 \mathrm{~g} \mathrm{COD} \mathrm{m}^{-3}$. The bulk liquid was assumed to be well mixed, and the external mass transfer limitations were neglected to simplify the evaluation. The hydraulic retention time (HRT) was set to $1 / 4 \mathrm{~d}$ and the sludge retention time (SRT) was equal to HRT. Besides, the porosity of the granules was chosen to be $80 \%$ and initial biomass fractions in the bulk liquid were all 0.01 .

The model simulation time was set to 5000 days to assure that a steady-state has been reached in the granules. Besides, to evaluate the dynamic simulations of the granules with the presence and absence of NOB, we firstly simulated biomass fractions in the steady-state granules at different COD levels (NOB was hardly present in the granules). Then, we chose the steady-state biomass fractions as the initial conditions for dynamic simulations of the granules with the absence of NOB. Finally, the initial AOB, NOB, AMX, HET, and INT fractions in the granules were multiplied by 0.8 , and then added 0.2 times of the initial NOB fraction of steady-state simulation to assess the effect of the contribution of the PD process on the reactor with the presence of NOB.

\section{Results And Discussion}

\section{Contribution of PD to nitrogen removal with the presence and absence of NOB}

A series of dynamic simulations were performed for the influent contained only ammonium and no organic carbon, and the influent contained ammonium and organic carbon with the presence and absence of NOB.

\section{Contribution of PD to nitrogen removal with NOB}

The contribution of $A M X$ and denitrification to nitrogen removal under different influent COD are shown in Fig. 1. It was clear that the PD process was not beneficial for nitrogen removal with the presence of NOB. 
Fig. 1a displays that the removal of nitrogen was entirely dependent on AMX and the optimum DO was $0.3 \mathrm{mg} / \mathrm{L}$ with maximum TNR at $80 \%$ when the influent had no organic carbon. TNR was deteriorated at high DO levels. When the influent COD was increased to $100 \mathrm{mg} / \mathrm{L}$, Fig. $1 \mathrm{~b}$ shows that the higher the influent COD, the higher the optimum DO level ( $D O=0.7 \mathrm{mg} / \mathrm{L}$ ) because both COD oxidation and nitrification consumed oxygen and a higher oxygen flux towards the granule was needed at increasing COD. In addition, the metabolism of $\mathrm{N}$ could be divided into denitrification and anammox pathways due to the presence of COD. The optimal TNR decreased to around 50\% that meant the influent COD leading to poor nitrogen removal when considering $\mathrm{NOB}$ presenting in the reactor. Due to a part of $\mathrm{NO}_{2}^{-}$was reduced to $\mathrm{N}_{2}$ by one-stage denitrification bacteria (DB) and a part of $\mathrm{NO}_{2}^{-}$was consumed by $\mathrm{NOB}$, so a large accumulation of nitrite could not be achieved inside the granule (Zhang et al. 2020) and AMX activity became lower. Although the influent COD was high, we found that AMX was the major contributor to nitrogen removal at any DO level, which was consistent with previous studies (Cui et al. 2017; Du et al. 2019). When the influent COD was increased to $300 \mathrm{mg} / \mathrm{L}$ (Fig. 1C), the DO level required for optimal TNR had not changed, and the contribution of denitrification was increased compared to the influent COD = $100 \mathrm{mg} / \mathrm{L}$ situation, while the contribution of AMX was reduced. Furthermore, the increasing contribution of denitrification was not a good phenomenon which meant that the short-cut denitrification we expected to achieve was reduced, so we seemed not to achieve an efficient PD process in a one-stage reactor with the presence of NOB.

The above three scenarios were simulated under the assumption of MLVSS $=3000 \mathrm{mg} / \mathrm{L}$ in the granule. When we increased biomass and assumed MLVSS $=6000 \mathrm{mg} / \mathrm{L}$ under influent COD $=300 \mathrm{mg} / \mathrm{L}$, we found that TNR and the contribution of AMX increased much (Fig. 1d) compared to MLVSS $=3000 \mathrm{mg} / \mathrm{L}$, indicating that the short-cut denitrification process and the activity of AMX were enhanced when biomass in the granule was increased. The simulation result in Fig. 1d shows that after doubling biomass in the granule, the optimum DO was decreased from $0.7 \mathrm{mg} / \mathrm{L}$ to $0.5 \mathrm{mg} / \mathrm{L}$. It can be inferred that the more MLVSS in the granule, the more beneficial to remove nitrogen under high influent COD conditions.

The impact of COD on the PD process is important, which had been confirmed by large experiments (Du et al. 2014; Le et al. 2019; Ma et al. 2020). Comparing to the case of influent COD $=100 \mathrm{mg} / \mathrm{L} \mathrm{(Fig.} \mathrm{1b),}$ the higher influent COD (Fig. 1c) resulted in higher heterotrophic biomass, which led to a higher contribution of denitrification and was in line with the simulation results of Hubaux et al. (2015). Meanwhile, the simulation results also demonstrated that the contribution of denitrification was $60 \%$ when influent COD $=900 \mathrm{mg} / \mathrm{L}$. Chamchoi et al. (2008) suggested that when influent COD was more than $300 \mathrm{mg} / \mathrm{L}$ without aeration, AMX were completely inactivated and replaced by DB.

From Fig .1 we can derive that the presence of COD also promoted the DO range required for high TNR becoming broader. Hubaux et al. (2015) compared the contribution of AMX with that of denitrifying bacteria to nitrogen removal and they found that increasing COD appropriately led to an increase in the robustness of the granular sludge reactor to changes in DO. 
A special situation aroused when the influent COD was very low, as shown in Fig. 2. The simulation result demonstrated that TNR was higher in the case of low influent COD when NOB was present, in agreement with the results of Mozumder et al. (2014). When the influent COD was reduced to only $10 \mathrm{mg} / \mathrm{L}$, we were surprised to find that the PD process resulted in increasing the activity of AMX and optimal TNR compared to the absence of COD, suggesting that the PD process helped to improve nitrogen removal under very low COD concentration, even in the presence of NOB.

Therefore, the PD process was bad to improve nitrogen removal under high influent COD conditions but slightly increasing TNR at very low COD levels with the presence of NOB. Moreover, although the PD process was not good for nitrogen removal at high COD levels, it widened the optimum DO range so that making operation conditions easier to achieve high TNR.

\section{Contribution of PD to nitrogen removal without NOB}

As shown in Fig. 3, we analyzed the contribution of PD to nitrogen removal assuming NOB was absent and it was reassuring to discover that PD improved nitrogen removal under different influent COD conditions. When the influent had no organic carbon (Fig. 3a), the optimum DO was also at $0.3 \mathrm{mg} / \mathrm{L}$ compared to the presence of NOB, with the difference that the optimal TNR was higher than that with the presence of NOB. When COD $=100 \mathrm{mg} / \mathrm{L}$ (Fig. 3b), the optimal TNR was achieved a little increasing compared to no COD condition. Not only the optimum DO level $(\mathrm{DO}=0.7 \mathrm{mg} / \mathrm{L})$ had not been changed compared to the situation with the presence of NOB, but also the DO range for TNR above $80 \%$ was widened, indicating that the PD process helped to improve nitrogen removal with the absence of NOB. When COD was increased to $300 \mathrm{mg} / \mathrm{L}$ (Fig. 3C), the contribution of denitrification was increased. Fig. 3c shows that although AMX activity was inhibited, the optimal TNR was not affected if we made the reactor at a high DO level ( $D O=1.5 \mathrm{mg} / \mathrm{L}$ ). After increasing MLVSS to $6000 \mathrm{mg} / \mathrm{L}, \mathrm{AMX}$ activity was restored, and the optimal TNR was further increased at a lower DO level which was also similar to the simulation results with the presence of NOB.

Without considering NOB, the PD process not only helped to widen the optimum DO range but also increased the optimal TNR slightly. However, if the influent COD was high and DO was low, HET utilized sufficient COD for a complete denitrification process and was therefore unable to achieve a significant accumulation of $\mathrm{NO}_{2}{ }^{-}$in the granule, which was not conducive to increasing the activity of AMX. From the simulation results, we could conclude that the PD process could be implemented for efficient nitrogen removal with the absence of NOB even at high COD levels.

The effluent $\mathrm{NO}_{3}{ }^{-}$concentration at different $\mathrm{COD}$ and $\mathrm{DO}$ levels were compared for the cases with and without NOB (Fig. 4). From the simulation results, when the influent COD and the bulk oxygen was appropriately increased (Fig. $4 \mathrm{~b}, 4 \mathrm{c}$ and $4 \mathrm{~d}$ ), the effluent $\mathrm{NO}_{3}{ }^{-}$concentration was considerably reduced (almost no $\mathrm{NO}_{3}{ }^{-}$in the effluent) compared to the no organic carbon influent with the absence of NOB because the heterotrophic bacteria reduced the $\mathrm{NO}_{3}{ }^{-}$produced by $\mathrm{AMX}$ to $\mathrm{NO}_{2}{ }^{-}$through partial denitrification, and this conclusion was similar to the result of the model simulations by Mozumder et al. 
(2014). However, when considering $\mathrm{NOB}$, we found that the effluent $\mathrm{NO}_{3}{ }^{-}$concentration was still high because a large amount of NOB produced much $\mathrm{NO}_{3}{ }^{-}$at high DO levels. Hence, TNR was not satisfied when NOB was present. In conclusion, the PD process without NOB can solve the problem of a one-stage autotrophic reactor.

\section{Influence of combined COD and DO on TNR and the analysis of microbial communities}

The influence of combined COD and DO on steady-state reactor performance is shown in Fig. 5. For a previous study, it was considered that more efficient coupling of PD to anammox would be to keep the DO below $0.7 \mathrm{mg} / \mathrm{L}$, however, the author just considered the effect of DO on the reactor without COD in the wastewater (You et al. 2020). The simulation results in Fig. 5 showed that when the influent COD > 50 $\mathrm{mg} / \mathrm{L}$, the optimum DO $>0.5 \mathrm{mg} / \mathrm{L}$, which meant that once the influent COD was increased, we could achieve high TNR at high DO levels. As mentioned previously, it could also be inferred from Fig. 5 that the DO levels corresponding to high TNR became wider at moderate influent COD. Numerous experiments and model simulations have also demonstrated that increased COD could lead to significantly higher TNR and a wider DO range (Giustinianovich et al. 2016; Hubaux et al. 2015) at steady-state. As a result, we could better control the DO concentration to achieve maximum TNR. Previous studies of the two-stage reactors or one-stage reactors without aeration have been considered to be unsuitable for removing wastewater that contained residual COD, however, the simulation results of this model could give a good direction that even in the presence of COD in the wastewater, we could increase the concentration of DO so that most of the COD was consumed in the outer layer of the granule by aerobic heterotrophs (Fahmi et al. 2020)

It is necessary to analyze the distribution of biomass in the granule that can be helpful for us to explain why the PD process improved nitrogen removal at steady-state. There have been many previous documents on the analysis of microbial communities of heterotrophic and autotrophic bacteria in granule/biofilm in the one-stage or two-stage reactors (Li et al. 2019; Shi et al. 2019; Xu et al. 2020), for the PD process, we wished to be able to enrich Thauera (denitrifying heterotrophic bacteria with $\mathrm{NO}_{3}{ }^{-}$as an electron acceptor) in the granule/biofilm to achieve high TNR. So, the reason why PD process is more efficient and economical than conventional nitrogen removal is mainly due to the coexistence of a variety of micro-organisms which results in a greater accumulation of $\mathrm{NO}_{2}^{-}$. As autotrophs and heterotrophs can coexist in the granule, this means that it is important to study both COD and DO parameters to balance them to achieve a satisfactory TNR. Fig. 6 gives us a good overview of the simulation results of autotrophic and heterotrophic bacteria proportion at different COD and DO levels. Aeration in the onestage reactor resulted in the presence of $\mathrm{AOB}$ and $\mathrm{NOB}$ in the outer layer of the granule and it has been demonstrated that the sequence of biological reactions in the granule/biofilm started with the aerobic oxidation of COD followed by the nitrification process of AOB (Zhou et al. 2020; Zhou et al. 2018). Fig. 6a showed that $A O B$ steady-state fraction had a lower share in the granule at high influent COD levels. This was because the aerobic heterotrophic bacteria located in the outermost layer of the granule had significantly higher biomass and AOB were outcompeted by them at high COD levels (Fig. 7b). From Fig. 
$6 a$ and Fig. 6b, even if there was sufficient DO at high COD levels, AOB and NOB steady-state fraction were low because they were competed by HET for the spatial position. The result from Fig. $6 \mathrm{~b}$ was the same as the simulation of Mozumder et al. (2014) in that in the presence of HET and COD, the steadystate NOB fraction was lower and only became progressively higher when the wastewater was almost free of COD and DO $>0.6 \mathrm{mg} / \mathrm{L}$. When influent COD $>100 \mathrm{mg} / \mathrm{L}$, NOB were always absent within the granule regardless of the DO levels at steady-state. Therefore, when the reactor was in steady-state, we did not need to be concerned that the presence of NOB would have a negative effect on nitrogen removal at high COD levels. Based on the conclusion in the previous section, we could conclude that the PD process helped to improve nitrogen removal in a steady-state reactor even at high COD levels.

We can think of the heterotrophic bacteria in the granule as mainly of two types as aeration heterotrophs and anoxic heterotrophs. Aerobic heterotrophic bacteria are responsible for degrading most of the COD in the outermost layer of the granule (Zhou et al. 2018), allowing denitrifying bacteria (DB) located in the slightly inner anoxic zone of the granule, to carry out a partial denitrification process with $\mathrm{NO}_{3}{ }^{-}$as the electron acceptor. We could find that at high DO and COD levels (Fig. 6c), a high proportion of heterotrophic bacteria (50\%) could be found in the granule, which were mainly aerobic heterotrophs, not anoxic heterotrophs (Hao and van Loosdrecht 2004). The result of Fig. 6d showed that steady-state AMX fraction maintained high at low DO levels. If the influent COD was increased appropriately, then the DO levels required for higher steady-state AMX fraction became wider that corresponding to the results in the previous section. When DO $>0.5 \mathrm{mg} / \mathrm{L}$ and COD $>50 \mathrm{mg} / \mathrm{L}$, TNR could achieve above $90 \%$, however, the steady-state AMX fraction was not the highest under these conditions. This was suggested that AMX was not most active when the steady-state fraction was the highest. In general, we should control the DO concentration so that the three types of functional bacteria, AOB, HET, and AMX, can better co-exist within the granule and achieve optimal TNR at different COD levels.

The position of different microbial communities in the granule is determined by their competition for substrates and space. The previous study has been demonstrated that AMX, HET, and AOB can coexist in the granule (Zhou et al. 2020). It has been found that AOB are usually located on the outside of the granule and $A M X$ are located deeper in the granule in terms of profile biomass distribution (Mozumder et al. 2014), whereas aerobic heterotrophs are located on the outermost surface of the granule, DB are located in the anoxic zone of the granule (Zhou et al. 2018). Typical steady-state biomass distribution profiles without considering NOB in the model are displayed in Fig. 7. When influent COD was $10 \mathrm{mg} / \mathrm{L}$, Fig. 7a showed that the anaerobic zone in the granule was dominated by AMX, while only a small amount of $A O B$ were present due to oxygen limitation. On the one hand, at $R / R_{\max }=0.7$ of the granule, the growth rate of $A O B$ accelerated due to the increased oxygen flux and increased as it approached the outer surface of the granule, while AMX were largely inactive due to its sensitivity to oxygen. On the other hand, aerobic heterotrophs had lower biomass because of the absolute dominance of AOB and less COD on the outer surface of the granule. When influent COD was $100 \mathrm{mg} / \mathrm{L}$ (Fig. 7b), the result showed that AMX were still occupied the anaerobic zone in the interior of the granule, and the AMX biomass wherein the same location was slightly higher than the low influent COD condition (Fig. 7a). This was because when 
the influent COD concentration was increased, the biomass of denitrifying heterotrophic bacteria (DB) outside the granule increased, converting the $\mathrm{NO}_{3}{ }^{-}$produced by $\mathrm{AMX}$ into $\mathrm{NO}_{2}{ }^{-}$available to $\mathrm{AMX}$, resulting in an accumulation of $\mathrm{NO}_{2}{ }^{-}$in the interior of the granule (Shi et al. 2019; Zhang et al. 2020) and the higher AMX biomass. However, compared to the low influent COD condition, AMX biomass started to decrease at granule $R / R_{\max }=0.6$ because the optimum bulk oxygen concentration increased due to the increasing COD concentration, thus reducing the anaerobic zone thickness. Besides, in the outermost layer of the granule, where the aerobic heterotrophs dominated due to sufficient bulk oxygen and COD (heterotrophic bacteria grew faster than autotrophic bacteria), AOB were outcompeted by the aerobic heterotrophs and AOB were present just below them (Zhou et al. 2020; Zhou et al. 2018). In general, COD and DO are almost completely depleted by the outer HET and $A O B$, thus forming an anoxic zone in the mid-granule, where $\mathrm{DB}$ reduced only $\mathrm{NO}_{3}{ }^{-}$to $\mathrm{NO}_{2}{ }^{-}$using limited $\mathrm{COD}$ (partial denitrification), which is consistent with Hao et al. who found that the maximum concentration of HET occurred in the outer layer of the granule (Hao and van Loosdrecht 2004). Studies have shown that as COD increased too high, the total number of AMX decreased, and the thickness of heterotrophic bacteria in the granule increased. What we would like to see in the reactor $\mathrm{s}$ was a significant accumulation of $\mathrm{NO}_{2}{ }^{-}$in the granule and an increase in $\mathrm{AMX}$ activity leading to higher TNR.

\section{Influence of combined influent $\mathrm{C} / \mathrm{N}$ and $\mathrm{DO}$ on $\mathrm{TN}$ removal under stable operation}

To evaluate the effect of influent $\mathrm{COD} / \mathrm{NH}_{4}{ }^{+}$on nitrogen removal at steady-state, further simulations with different $\mathrm{C} / \mathrm{N}$ and DO levels were run at a fixed $\mathrm{NH}_{4}{ }^{+}$concentration (Fig. 8). As mentioned before, simulations have shown that changes in influent COD could influence the distribution of microorganisms in the granule, TNR, and the optimum bulk oxygen concentrations on the PD process.

Previous experiments have demonstrated that influent $\mathrm{C} / \mathrm{N}$ has a significant impact on the PD process. First, the nature of the microbial community in the granule/biofilm at high $\mathrm{C} / \mathrm{N}$ and low DO levels was complex and existed functional species such as AOB, heterotrophs, AMX, etc. (Zhou et al. 2018). Second, when $\mathrm{C} / \mathrm{N}>1$, AMX was eliminated by $\mathrm{DB}$, leading to a deterioration in nitrogen removal (Chen et al. 2016; Tang et al. 2010), and AMX activity was inhibited when $C / N>2$ (Tang et al. 2010). Some simulations have shown that when $\mathrm{C} / \mathrm{N}$ was increased from $0.1: 3$ to $4: 3, \mathrm{AMX}$ activity and TNR were significantly reduced at low DO levels (Hubaux et al. 2015). However, AMX activity appeared to be improved at moderate DO levels, probably due to the consumption of COD by the outer growth of aerobic HET, which resulted in decreasing the $\mathrm{C} / \mathrm{N}$ in the granule, enhancing $\mathrm{AMX}$ activity, and TNR. The experimental concluded that AMX could not compete with DB at high $\mathrm{C} / \mathrm{N}$ levels (reactor operation up to the 139-153 $\mathrm{d}$ and $\mathrm{C} / \mathrm{N}=4, \mathrm{AMX}$ has significantly inhibited with only $24.39 \% \mathrm{NH}_{4}{ }^{+}$removal efficiency, compared to the contribution of $29.47 \%$ for AMX and $68.91 \%$ for DB in the nitrogen removal process), and the biggest reason was that there was an insufficient accumulation of nitrite in the granule. Fig. 8a showed the contribution of $A M X$ to nitrogen removal under different $D O$ and $C / N$ conditions. Simulation results showed that even at higher influent $\mathrm{C} / \mathrm{N}$ levels, $\mathrm{AMX}$ was still the main contributor to $\mathrm{TN}$ removal when bulk oxygen concentration was high. Therefore, increasing bulk oxygen concentration allowed aerobic 
heterotrophs to proliferate faster and degrade COD that resulting in lower $\mathrm{C} / \mathrm{N}$ in the granule without affecting AMX activity, and Lackner et al. (2008) got the same result. The result in Fig. 8b showed that influent $\mathrm{C} / \mathrm{N}$ also influenced the contribution of denitrification to nitrogen removal that was not the main contributor to TN removal (maximum contribution rate of denitrification was only $7 \%$ ), which was in line with the conclusions drawn from a large number of experiments (Cao et al. 2017; Cao et al. 2016). This meant that influent $\mathrm{C} / \mathrm{N}$ affected the partial denitrification process, therefore controlling the influent $\mathrm{C} / \mathrm{N}$ allowed equilibrium between $\mathrm{AMX}$ and $\mathrm{DB}$ within the granule, making $\mathrm{PD}$ process nitrogen removal more efficient. If influent $\mathrm{C} / \mathrm{N}$ was high to allow complete denitrification (a conventional biological denitrification process can be complete at $\mathrm{C} / \mathrm{N}>5-8$ theoretically), we could be able to inhibit complete denitrification by increasing bulk oxygen concentration to decrease denitrification contribution rate (Fig. 8b). Studies have also been carried out based on influent C/N at 2-3 for the PD process (Du et al. 2016; $\mathrm{Ge}$ et al. 2012; $\mathrm{Ma}$ et al. 2017). Summing up the above analysis, we found that increasing influent $\mathrm{C} / \mathrm{N}$ also resulted in a wider range of optimum DO operating conditions for the reactor and the results (Fig. 8) once again indicated that the main contributor to TN removal was AMX.

\section{Influence of combined granule size and DO on TN removal under stable operation}

The influence of the granule size and DO on the overall steady-state reactor performance in terms of nitrogen removal with organic substrate present in the influent is shown in Fig. 9. The efficiency of autotrophic nitrogen removal could be considered not affected by the influent COD if the granule was large enough to allow little competition between $A O B, A M X$, and DB for space and there was sufficient DO (Fig. 9a).

Choi et al. (2018) assessed the contribution of AMX, AOB, and DB to nitrogen removal according to granule size and found that the contribution of microbial activity to nitrogen removal was significantly influenced by granule size. In the presence of COD, it was shown that the contribution of AMX to TN removal was higher for granule diameter larger than $1600 \mu \mathrm{m}$, whereas, for granule diameter smaller than $1600 \mu \mathrm{m}$, the contribution of AMX to nitrogen removal was unsatisfactory at any DO level (Fig. 9a). A simulation analysis of the effect of granule size on the nitrogen removal performance of a reactor by fixing bulk oxygen concentration at $1 \mathrm{mg} / \mathrm{L}$ and comparing the influent water with and without COD was carried out by Mozumder et al. (2014). This simulation showed that the presence of COD reduced the optimum diameter of the granule (the diameter of the granule was $3000 \mu \mathrm{m}$ with the presence of COD, compared to $4000 \mu \mathrm{m}$ for the optimal nitrogen removal without COD), and the optimal TNR became higher. The simulation result in Fig. 9b showed that the main contributor to TN removal was not denitrification at any granule diameter level in the steady-state reactor with the absence of NOB.

In summary, to achieve satisfactory nitrogen removal, we need to control the granule size for optimal AMX activity and the corresponding denitrification contribution was low so that we can achieve the PD process.

\section{Conclusions}


In this study, a 1D multi-population biofilm model was developed to evaluate the contribution of the PD process on the one-stage autotrophic nitrogen removal process with the presence and absence of NOB at influent $\mathrm{NH}_{4}{ }^{+}=100 \mathrm{mg} \mathrm{N} / \mathrm{L}$. The dynamic simulation results revealed that the optimum DO without influent organic carbon was $0.3 \mathrm{mg} / \mathrm{L}$. Although the PD process widened the optimum DO range, it decreased TNR with the presence of NOB. However, the PD process increased the optimal TNR and the effluent nitrate was significantly decreased with the absence of NOB. The steady-state simulation results showed that the optimum oxygen concentration was over $0.5 \mathrm{mg} / \mathrm{L}$ when influent COD was over 50 $\mathrm{mg} / \mathrm{L}$. When the influent COD was high, TNR could be increased by increasing bulk oxygen concentration. At high DO and COD levels, a high proportion of heterotrophic bacteria (50\%) could be found and NOB were always absent in the granules. Besides, higher influent $\mathrm{C} / \mathrm{N}$ also resulted in a wider range of optimum DO ranges and the AMX were the main contributor to TN removal. The contribution of AMX to nitrogen removal was higher for granule diameter larger than $1600 \mu \mathrm{m}$.

\section{Declarations}

\section{Ethics approval and consent to participate}

Not applicable

\section{Consent for publication}

Not applicable

\section{Availability of data and materials}

The datasets used and/or analysed during the current study are available from the corresponding author on reasonable request.

\section{Competing interests}

The authors declare that they have no competing interests.

\section{Funding}

Not applicable

\section{Authors' contributions}

CZ was a major contributor in writing the manuscript and run the model. LZY and MZ analyzed the biological modeling approach. WJ helped to helped to revise and improve the manuscript and answered technical difficulties. All authors read and approved the final manuscript.

\section{Acknowledgements}


Thanks to the Department of Municipal Engineering, School of Environmental Science and Engineering, Yangzhou University for technical assistance.

\section{References}

Cao SB, Peng YZ, Du R, Wang SY (2016): Feasibility of enhancing the DEnitrifying AMmonium OXidation (DEAMOX) process for nitrogen removal by seeding partial denitrification sludge. Chemosphere 148:403407

Cao SB, Du R, Li BK, Wang SY, Ren NQ, Peng YZ (2017): Nitrite production from partial-denitrification process fed with low carbon/nitrogen $(\mathrm{C} / \mathrm{N})$ domestic wastewater: performance, kinetics and microbial community. Chem Eng J 326:1186-1196

Cao SB, Oehmen A, Zhou Y (2019): Denitrifiers in Mainstream Anammox Processes: Competitors or Supporters? Environ Sci Technol 53(19):11063-11065

Chamchoi N, Nitisoravut S, Schmidt JE (2008): Inactivation of ANAMMOX communities under concurrent operation of anaerobic ammonium oxidation (ANAMMOX) and denitrification. Bioresour Technol 99(9):3331-3336

Chen CJ, Sun FQ, Zhang HQ, Wang JF, Shen YL, Liang XQ (2016): Evaluation of COD effect on anammox process and microbial communities in the anaerobic baffled reactor (ABR). Bioresour Technol 216:571578

Choi D, Cho S, Jung J (2018): Key operating parameters affecting nitrogen removal rate in single-stage deammonification. Chemosphere 207:357-364

Cui B, Liu XH, Yang Q, Li JM, Zhou XY, Peng YZ (2017): Achieving partial denitrification through control of biofilm structure during biofilm growth in denitrifying biofilter. Bioresour Technol 238:223-231

Du R, Peng YZ, Cao SB, Wu CC, Weng DC, Wang SY, He JZ (2014): Advanced nitrogen removal with simultaneous Anammox and denitrification in sequencing batch reactor. Bioresour Technol 162:316-322

Du R, Peng YZ, Cao SB, Wang SY, Wu CC (2015): Advanced nitrogen removal from wastewater by combining anammox with partial denitrification. Bioresour Technol 179:497-504

Du R, Peng YZ, Cao SB, Li BK, Wang SY, Niu M (2016): Mechanisms and microbial structure of partial denitrification with high nitrite accumulation. Appl Microbiol Biotechnol 100(4):2011-2021

Du R, Cao SB, Li BK, Niu M, Wang SY, Peng YZ (2017a): Performance and microbial community analysis of a novel DEAMOX based on partial-denitrification and anammox treating ammonia and nitrate wastewaters. Water Res 108:46-56 
Du R, Cao SB, Niu M, Li BK, Wang SY, Peng YZ (2017b): Performance of partial-denitrification process providing nitrite for anammox in sequencing batch reactor (SBR) and upflow sludge blanket (USB) reactor. Int Biodeterior Biodegrad 122:38-46

Du R, Cao SB, Li BK, Zhang HY, Wang SY, Peng YZ (2019): Synergy of partial-denitrification and anammox in continuously fed upflow sludge blanket reactor for simultaneous nitrate and ammonia removal at room temperature. Bioresour Technol 274:386-394

Fahmi B, Zhang XX, Wang YG, Wang CC, Xia YK, Wu P, Xu LZ (2020): New Insight into Partial Denitrification (PD)-based Anammox Process and Potential Engineering Application: A Review. Journal of Health and Environmental Research 6(3):79-86

Ganigue R, López H, Balaguer M, Colprim J (2007): Partial ammonium oxidation to nitrite of high ammonium content urban landfill leachates. Water Res 41:3317-3326

Ge SJ, Peng YZ, Wang SY, Lu CC, Cao X, Zhu YP (2012): Nitrite accumulation under constant temperature in anoxic denitrification process: The effects of carbon sources and COD/NO3-N. Bioresour Technol 114:137-143

Giustinianovich EA, Campos J-L, Roeckel MD (2016): The presence of organic matter during autotrophic nitrogen removal: Problem or opportunity? Sep Purif Technol 166:102-108

Hao XD, van Loosdrecht MCM (2004): Model-based evaluation of COD influence on a partial nitrificationAnammox biofilm (CANON) process. Water Sci Technol 49:83-90

Hubaux N, Wells G, Morgenroth E (2015): Impact of coexistence of flocs and biofilm on performance of combined nitritation-anammox granular sludge reactors. Water Res 68:127-139

Jin RC, Yang GF, Yu JJ, Zheng P (2012): The inhibition of the Anammox process: A review. Chem Eng J 197:67-79

Kartal B, Kuenen JG, van Loosdrecht MCM (2010): Sewage Treatment with Anammox. Science 328(5979):702

Lackner S, Terada A, Smets BF (2008): Heterotrophic activity compromises autotrophic nitrogen removal in membrane-aerated biofilms: Results of a modeling study. Water Res 42(4):1102-1112

Le T, Peng B, Su CY, Massoudieh A, Torrents A, Al-Omari A, Murthy S, Wett B, Chandran K, DeBarbadillo C, Bott C, De Clippeleir H (2019): Impact of carbon source and COD/N on the concurrent operation of partial denitrification and anammox. Water Environ Res 91(3):185-197

Li BL, Wang Y, Li JT, Yang L, Li X, Zhou Z, Li Y, Chen XG, Wu L (2019): The symbiosis of anaerobic ammonium oxidation bacteria and heterotrophic denitrification bacteria in a size-fractioned single-stage partial nitrification/anammox reactor. Biochem Eng J 151:107353 
Ma B, Qian WT, Yuan CS, Yuan ZG, Peng YZ (2017): Achieving Mainstream Nitrogen Removal through Coupling Anammox with Denitratation. Environ Sci Technol 51(15):8405-8413

Ma B, Xu XX, Wei Y, Ge CJ, Peng YZ (2020): Recent advances in controlling denitritation for achieving denitratation/anammox in mainstream wastewater treatment plants. Bioresour Technol 299:122697

Mozumder MS, Picioreanu C, van Loosdrecht MC, Volcke El (2014): Effect of heterotrophic growth on autotrophic nitrogen removal in a granular sludge reactor. Environ Technol 35(5-8):1027-1037

Mulder A, van de Graaf AA, Robertson LA, Kuenen JG (1995): Anaerobic ammonium oxidation discovered in a denitrifying fluidized bed reactor. FEMS Microbiol Ecol 16(3):177-183

Pérez J, Lotti T, Kleerebezem R, Picioreanu C, van Loosdrecht MCM (2014): Outcompeting nitrite-oxidizing bacteria in single-stage nitrogen removal in sewage treatment plants: A model-based study. Water Res 66:208-218

Shi LL, Du R, Peng YZ (2019): Achieving partial denitrification using carbon sources in domestic wastewater with waste-activated sludge as inoculum. Bioresour Technol 283:18-27

Sin G, Kaelin D, Kampschreur M, Takács I, Wett B, Gernaey K, Rieger L, Siegrist H, van Loosdrecht MCM (2008): Modelling nitrite in wastewater treatment systems: A discussion of different modelling concepts. Water Sci Technol 58:1155-1171

Sliekers AO, Derwort N, Gomez JLC, Strous M, Kuenen JG, Jetten MSM (2002): Completely autotrophic nitrogen removal over nitrite in one single reactor. Water Res 36(10):2475-2482

Strous M, Kuenen JG, Jetten MSM (1999): Key Physiology of Anaerobic Ammonium Oxidation. Appl Environ Microbiol 65(7):3248

Tang CJ, Zheng P, Wang CH, Mahmood Q (2010): Suppression of anaerobic ammonium oxidizers under high organic content in high-rate Anammox UASB reactor. Bioresour Technol 101(6):1762-1768

van Loosdrecht MCM, Hao XD, Jetten M, Abma W (2004): Use of Anammox in urban wastewater treatment. Water Sci Technol 4:87-94

Wang Z, Zhang L, Zhang FZ, Jiang H, Ren S, Wang W, Peng YZ (2019): Enhanced nitrogen removal from nitrate-rich mature leachate via partial denitrification (PD)-anammox under real-time control. Bioresour Technol 289:121615

Wang ZY, Shan XY, Li W, Chen H, Zhang M, Zheng P (2016): Robustness of ANAMMOX granule sludge bed reactor: Effect and mechanism of organic matter interference. Ecological Engineering 91:131-138

Wanner O, Reichert P (1996): Mathematical modeling of mixed-culture biofilms. Biotechnol Bioeng 49(2):172-184 
Xu XX, Ma B, Lu WK, Feng DB, Wei Y, Ge CJ, Peng YZ (2020): Effective nitrogen removal in a granulebased partial-denitrification/anammox reactor treating low C/N sewage. Bioresour Technol 297:122467

You QG, Wang JH, Qi GX, Zhou YM, Guo ZW, Shen Y, Gao X (2020): Anammox and partial denitrification coupling: a review. RSC Advances 10(21):12554-12572

Zhang T, Cao JS, Zhang YL, Fang F, Feng Q, Luo JY (2020): Achieving efficient nitrite accumulation in glycerol-driven partial denitrification system: Insights of influencing factors, shift of microbial community and metabolic function. Bioresour Technol 315:123844

Zhou X, Zhang ZQ, Zhang XA, Liu Y (2018): A novel single-stage process integrating simultaneous COD oxidation, partial nitritation-denitritation and anammox (SCONDA) for treating ammonia-rich organic wastewater. Bioresour Technol 254:50-55

Zhou X, Song JJ, Wang GL, Yin ZY, Cao XW, Gao JF (2020): Unravelling nitrogen removal and nitrous oxide emission from mainstream integrated nitrification-partial denitrification-anammox for low carbon/nitrogen domestic wastewater. J Environ Manag 270:110872

\section{Figures}
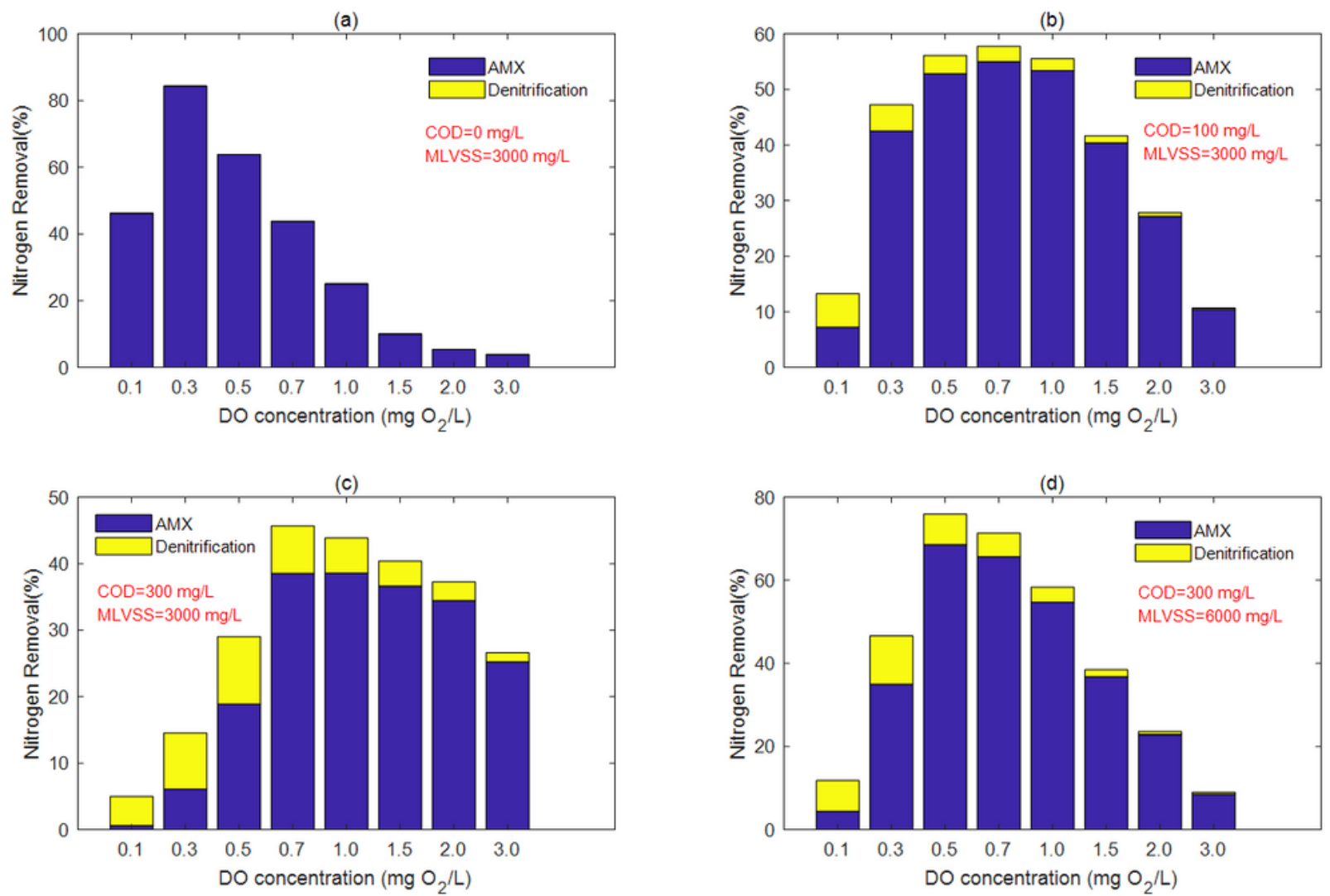

Figure 1 
Nitrogen removal contribution at (a) COD $=0 \mathrm{mg} / \mathrm{L}$, (b) COD $=100 \mathrm{mg} / \mathrm{L}$, (c) COD $=300 \mathrm{mg} / \mathrm{L}$, (d) COD = $300 \mathrm{mg} / \mathrm{L}$ with the presence of NOB

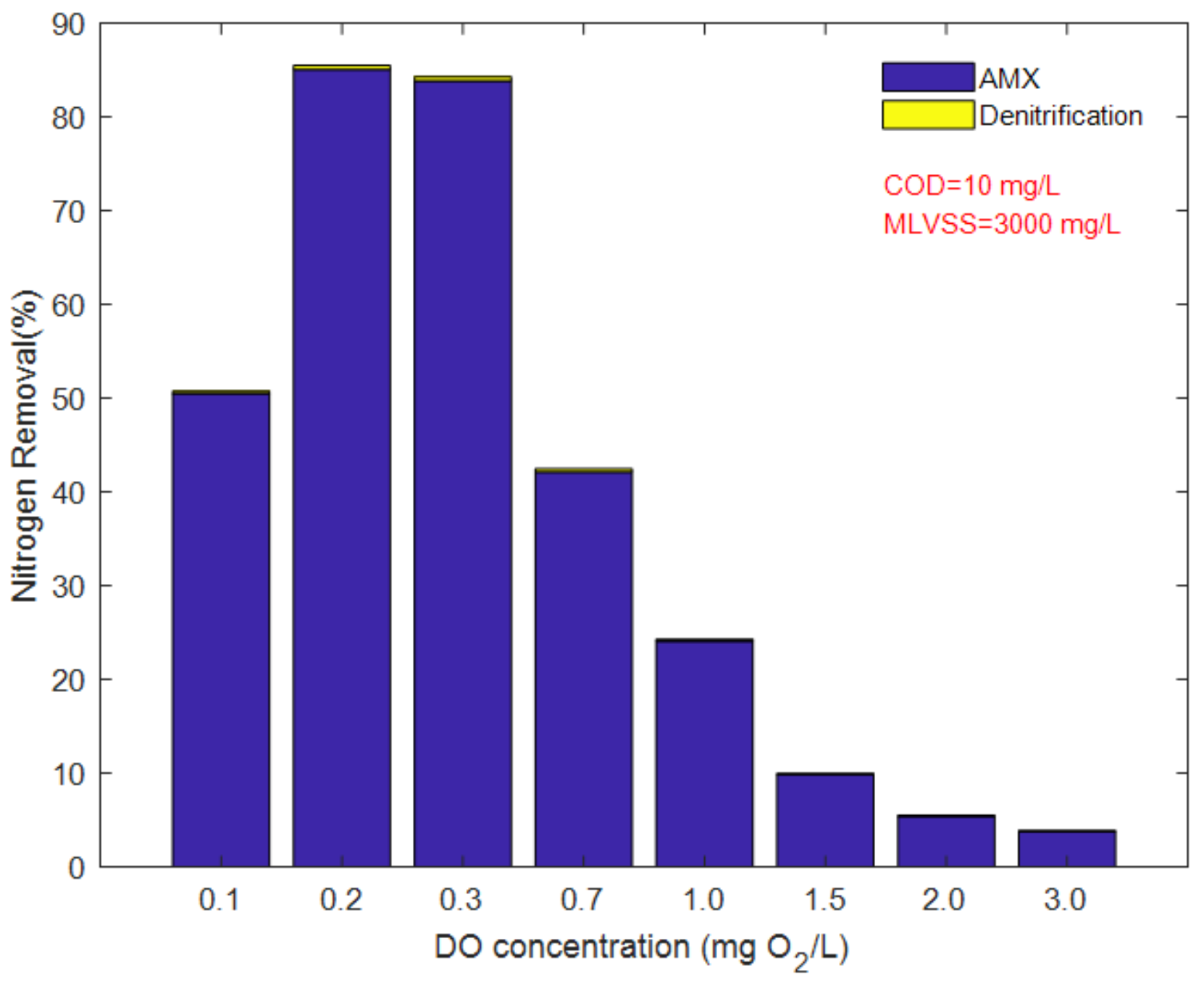

Figure 2

Nitrogen removal contribution for low COD concentration with the presence of NOB (COD $=10 \mathrm{mg} / \mathrm{L}$ ) 

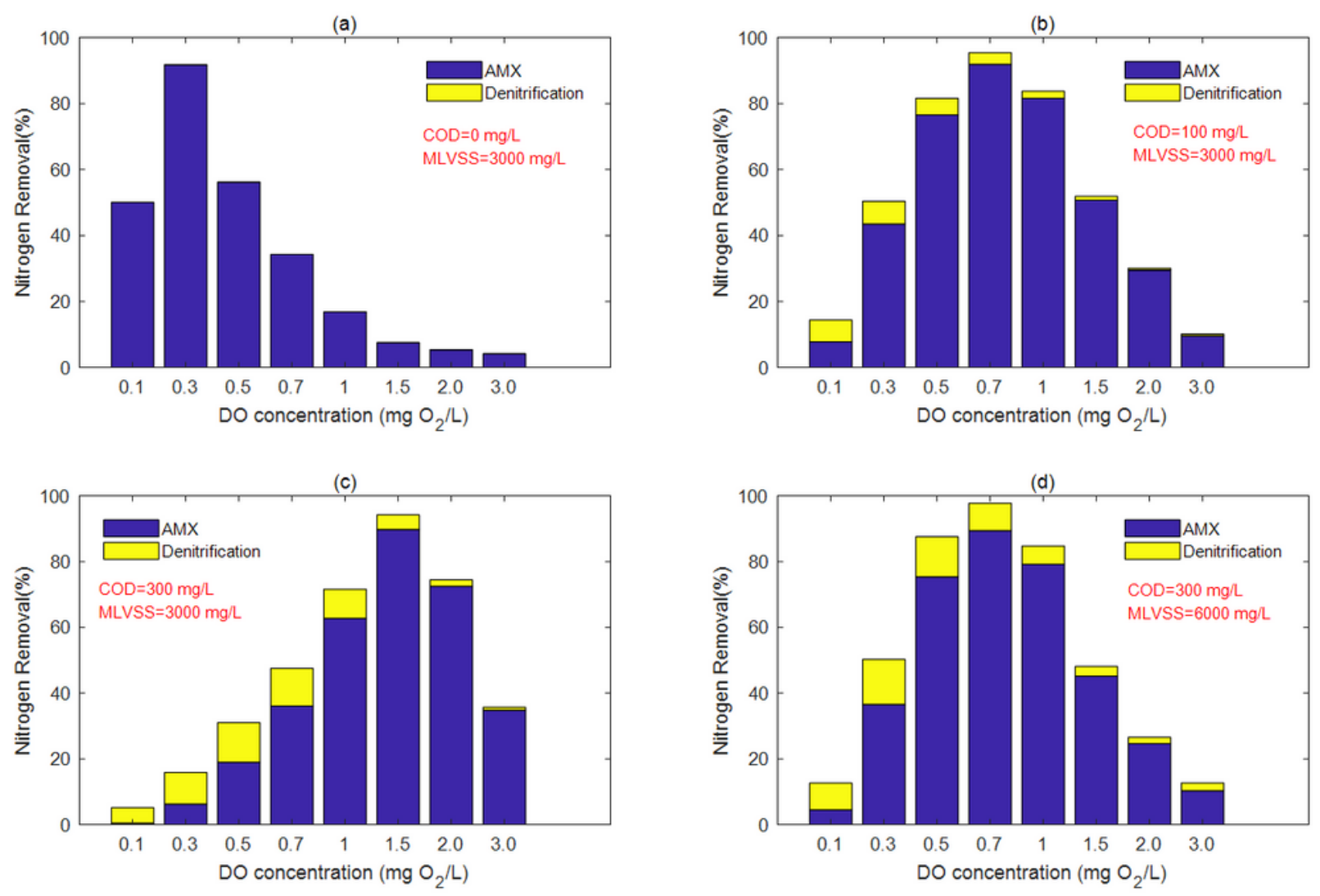

Figure 3

Nitrogen removal contribution at (a) COD $=0 \mathrm{mg} / \mathrm{L}$, (b) $C O D=100 \mathrm{mg} / \mathrm{L}$, (c) $\mathrm{COD}=300 \mathrm{mg} / \mathrm{L}$, (d) COD = $300 \mathrm{mg} / \mathrm{L}$ with the absence of NOB 

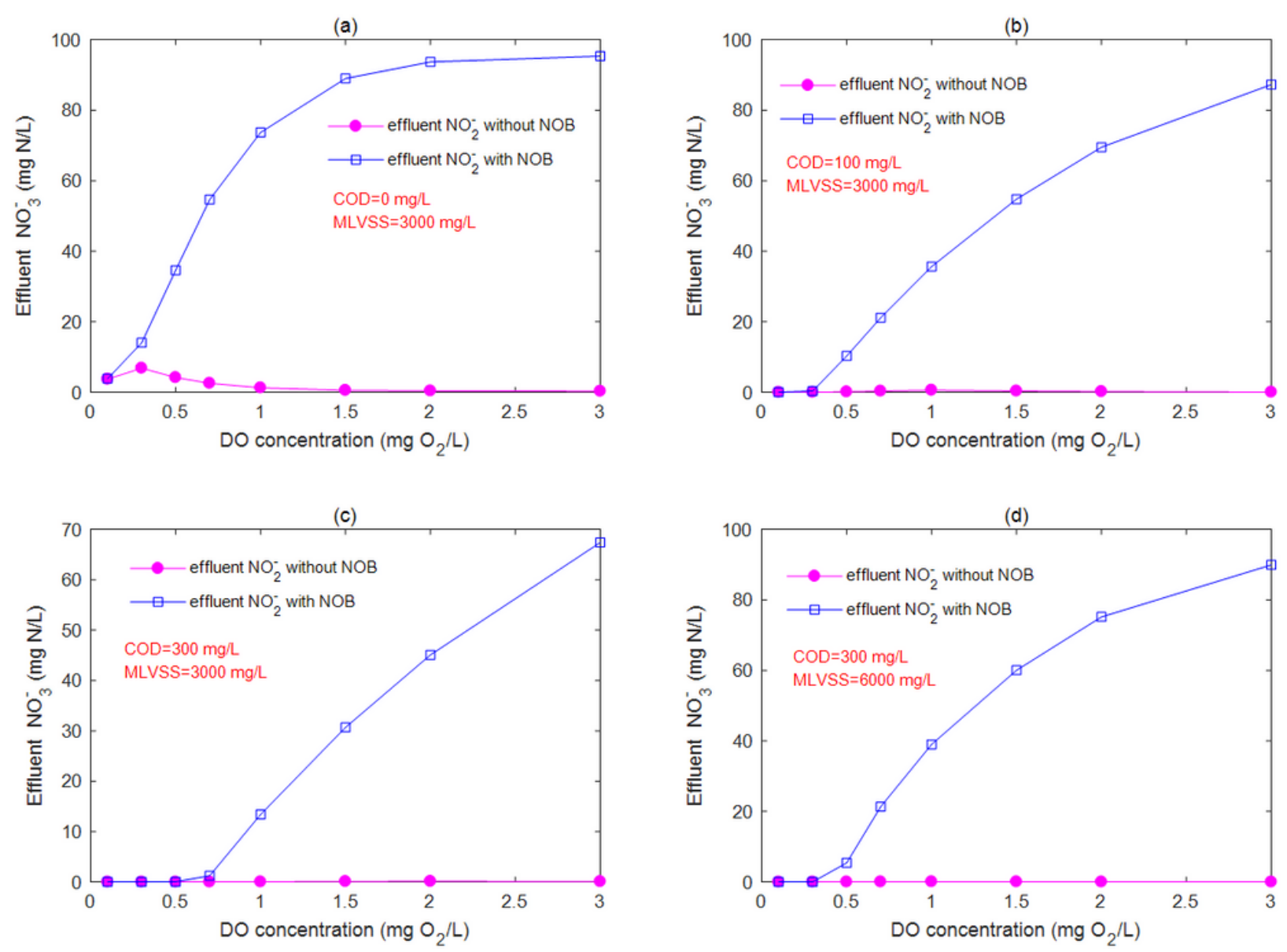

Figure 4

Effluent NO3- concentration with and without NOB at (a) COD $=0 \mathrm{mg} / \mathrm{L}$, (b) $\mathrm{COD}=100 \mathrm{mg} / \mathrm{L}$, (c) COD = $300 \mathrm{mg} / \mathrm{L}$, (d) COD $=300 \mathrm{mg} / \mathrm{L}$ 


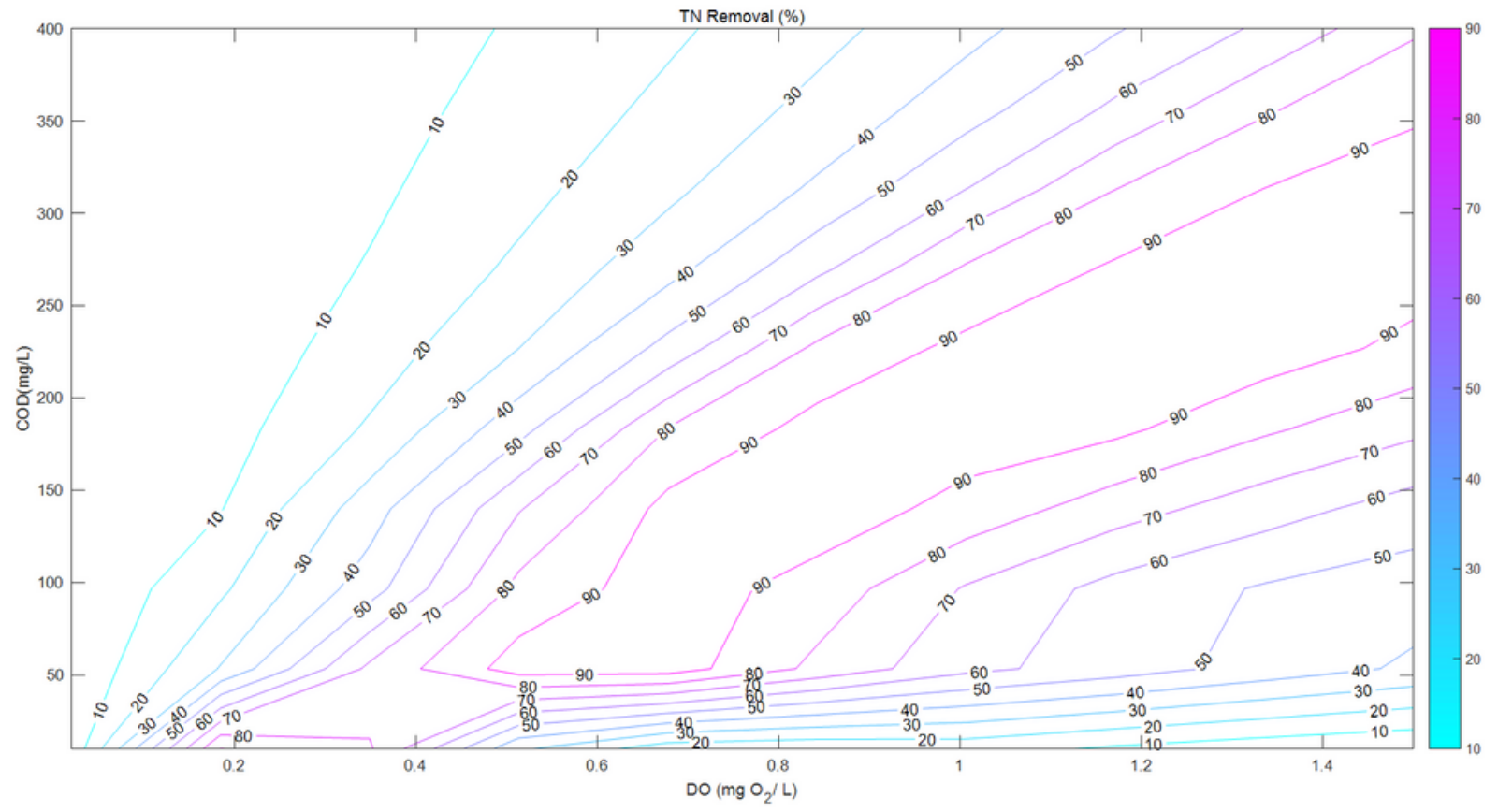

Figure 5

The combined impact of influent $\mathrm{COD}$ and $\mathrm{DO}$ concentration on the steady-state reactor performance (COD $=0$ to $400 \mathrm{mg} / \mathrm{L}$ and $\mathrm{NH} 4+=100 \mathrm{mg} \mathrm{N} / \mathrm{L}$ )
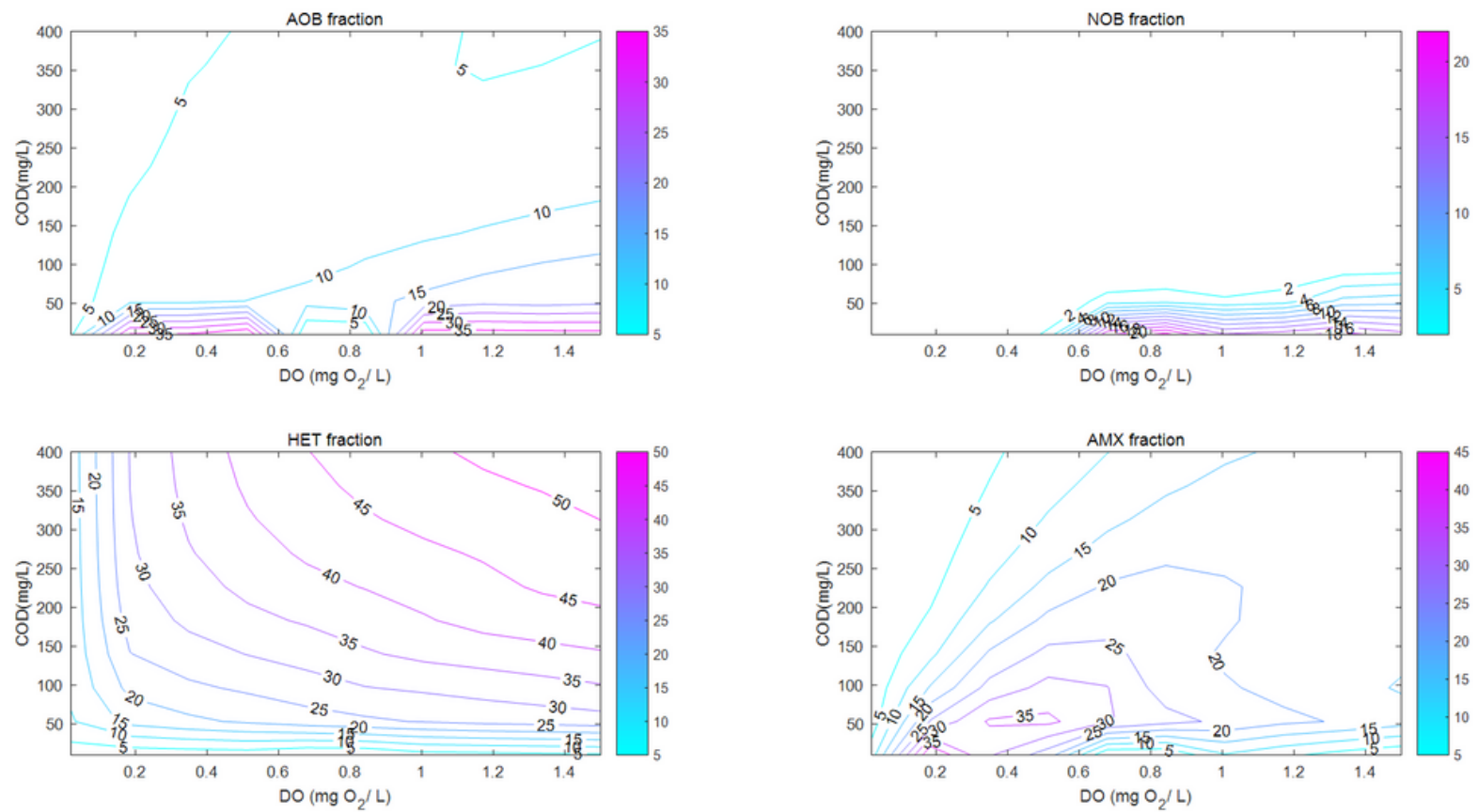

\section{Figure 6}

The combined impact of influent COD and DO concentration on the steady-state microbial fraction in the granule (COD $=0$ to $400 \mathrm{mg} / \mathrm{L}$ and $\mathrm{NH} 4+=100 \mathrm{mg} \mathrm{N} / \mathrm{L}$ ) 

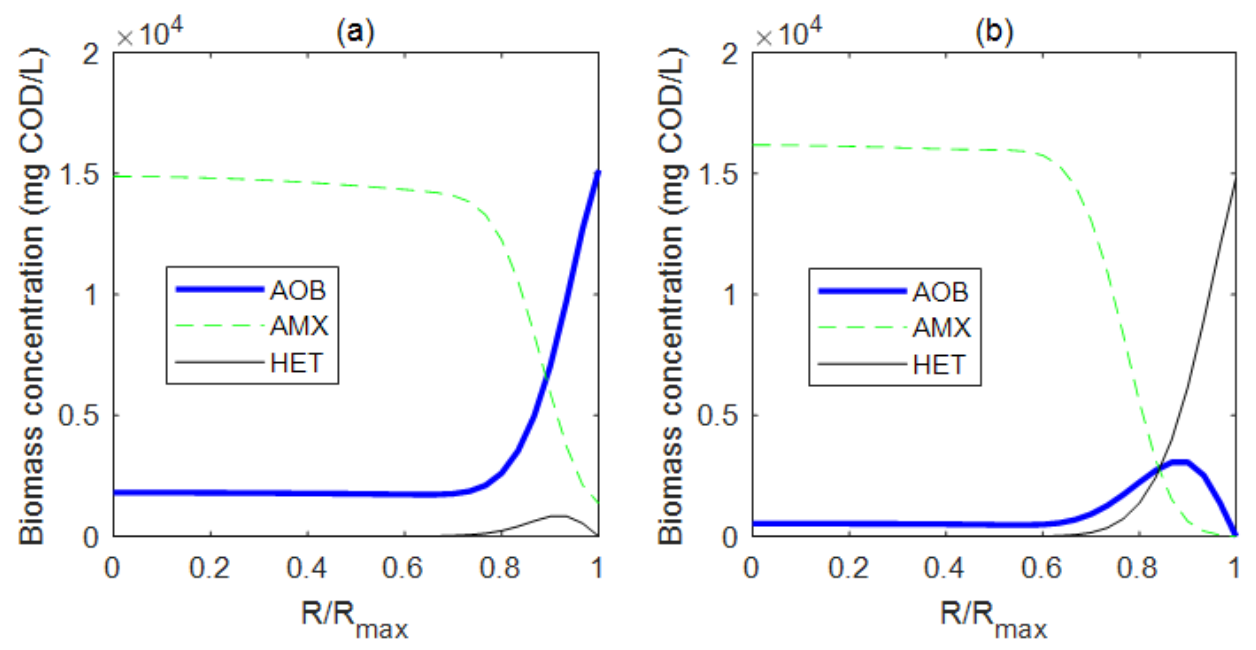

Figure 7

Steady-state distribution of $\mathrm{AOB}, \mathrm{AMX}$, and HET biomass in a granule under influent COD concentrations of (a) 10 and (b) $100 \mathrm{mg} / \mathrm{L}$ at optimum DO concentrations and NOB washed out in both cases
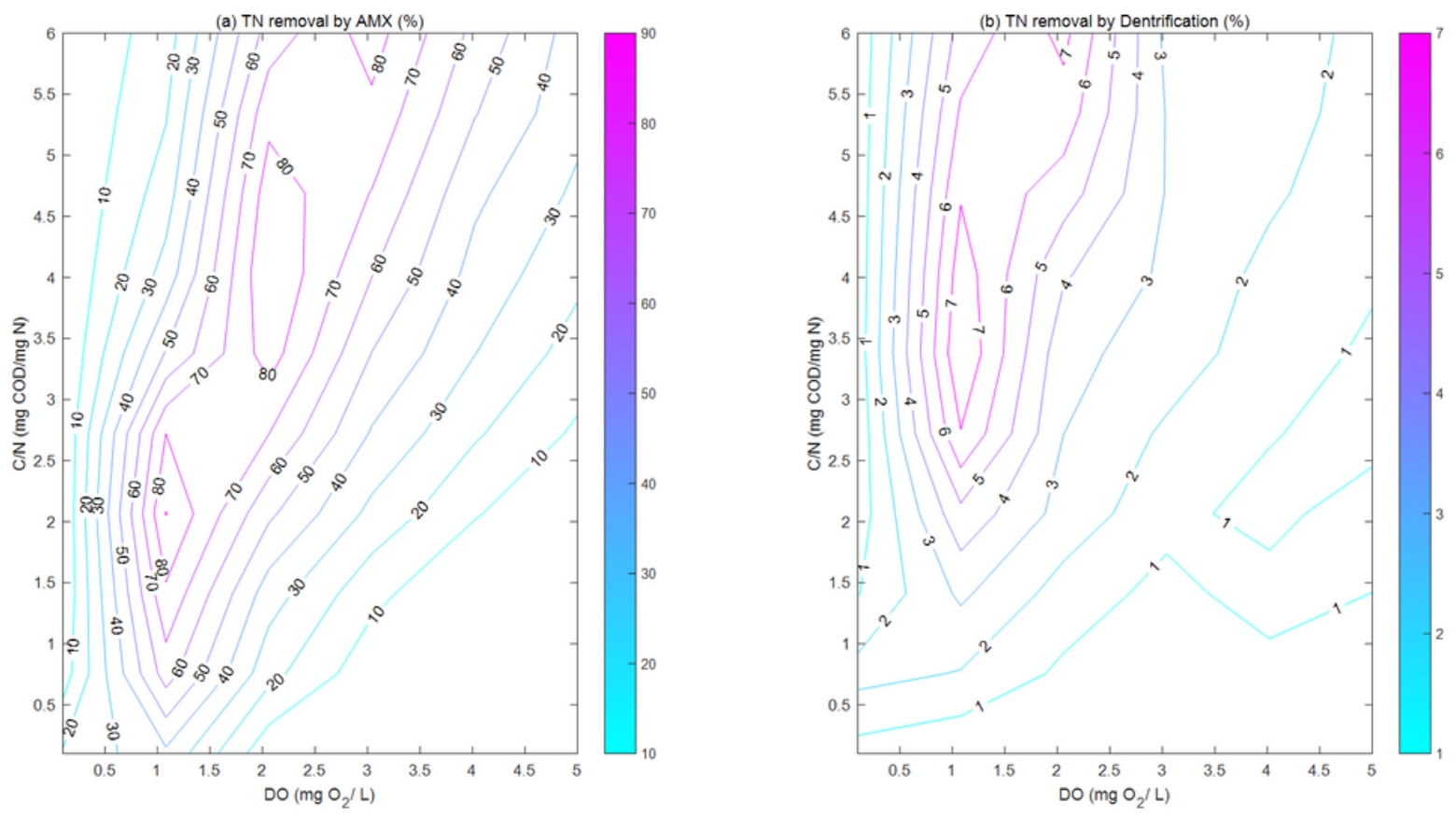

Figure 8 
Influence of combined influent $\mathrm{C} / \mathrm{N}$ and $\mathrm{DO}$ concentration on the steady-state reactor performances comparing (a) TN removal by AMX and (b) TN removal by denitrification (COD $=10$ to $600 \mathrm{mg} / \mathrm{L}$ and $\mathrm{NH} 4+=100 \mathrm{mg} / \mathrm{L})$
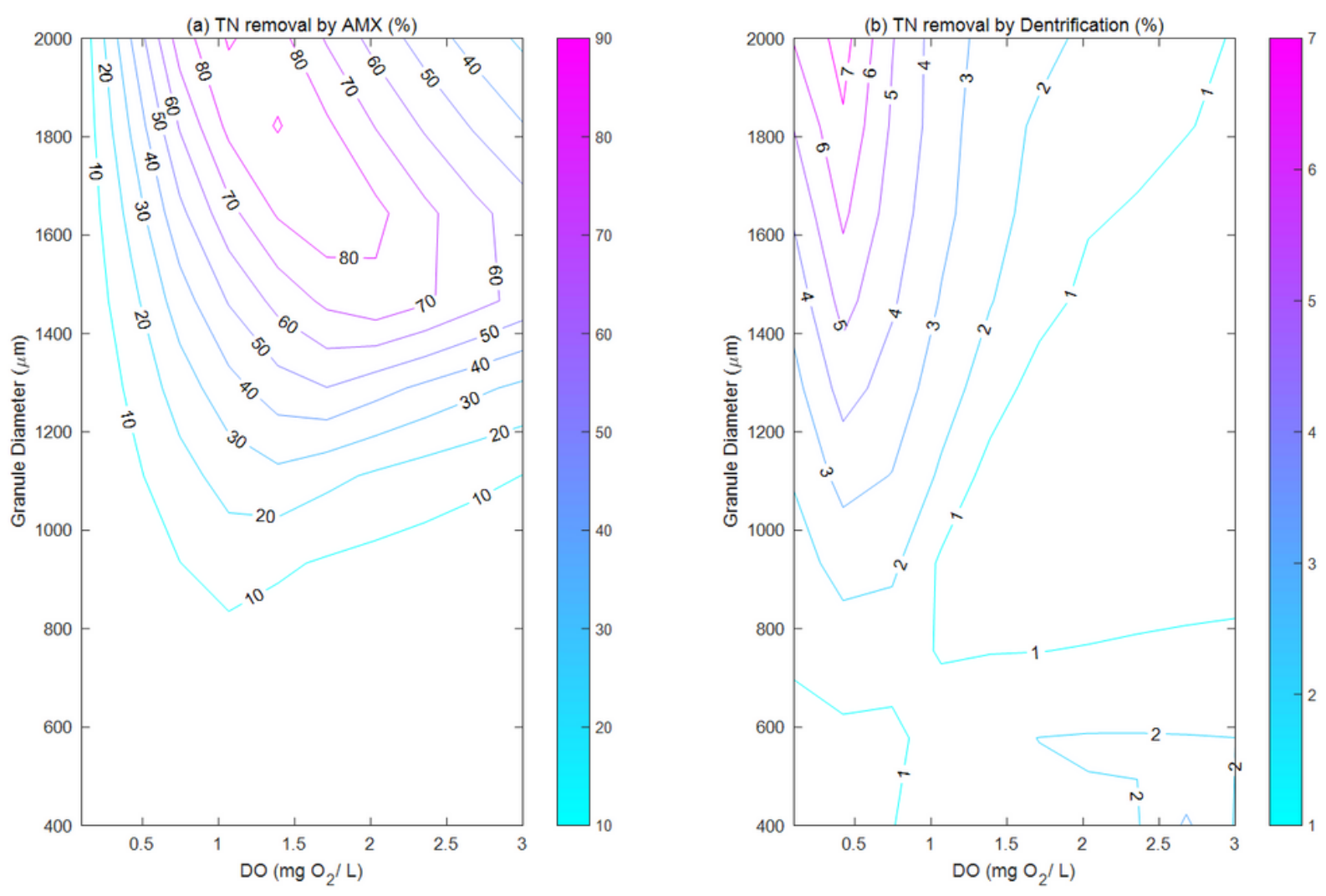

\section{Figure 9}

Influence of combined granule size and DO concentration on the steady-state reactor performances with the presence of COD comparing (a) TN removal by AMX and (b) TN removal by denitrification (COD = 100 $\mathrm{mg} / \mathrm{L}, \mathrm{NH} 4+=100 \mathrm{mg} / \mathrm{L}$ and granule diameters from 400 to $2000 \mu \mathrm{m}$ ).

\section{Supplementary Files}

This is a list of supplementary files associated with this preprint. Click to download.

- SupplementaryMaterial.doc 